\title{
COMPARATIVE STUDY OF WILD AND TRANSFORMED SALT TOLERANT BACTERIAL STRAINS ON TRITICUM AESTIVUM GROWTH UNDER SALT STRESS
}

\author{
Shazia Afrasayab, Muhammad Faisal*, Shahida Hasnain
}

Department of Microbiology \& Molecular Genetics, University of the Punjab, Quaid-e-Azam Campus, Lahore54590, Pakistan.

Submitted: January 11, 2010; Returned to authors for corrections: March 01, 2010; Approved: April 26, 2010.

\begin{abstract}
Eleven salt tolerant bacteria isolated from different sources (soil, plants) and their transformed strains were used to study their influence on Triticum aestivum var. Inqlab-91 growth under salt (100 mM NaCl) stress. Salt stress caused reduction in germination (19.4\%), seedling growth (46\%) and fresh weight (39\%) in non-inoculated plants. In general, both wild and transformed strains stimulated germination, seedling growth and fresh weight in salt free and salt stressed conditions. At $100 \mathrm{mM} \mathrm{NaCl}$, Staphylococcus xylosus ST-1 caused $25 \%$ increments in seedling length over respective control. Soluble protein content significantly enhanced (49\%) under salt stress as compared to salt free control. At $100 \mathrm{mM} \mathrm{NaCl}$ parental strain PT-5 resulted about $32 \%$ enhancement in protein content over respective control treatment. Salt stress induced the promotion of auxin content in seedlings. Overall, Bacillus subtilis HAa2 and transformed E. coli-SP-7-T, caused 33\% and 30\% increases in auxin content, respectively, were recorded under salt stress in comparison to control.
\end{abstract}

Key words: Triticum aestivum, Plasmid, Rhizobacteria, Salinity, Auxin, Transformation

\section{INTRODUCTION}

Inappropriate irrigation practices and lack of drainage have usually led to increase of salts in the soil which is detrimental to the crops. In Pakistan every year almost 120 million tones of salts in irrigation water are being added to the land and 40,000 hectares of agricultural land become damaged. In Pakistan about 6.30 million hectares of total land are salt affected (3) and agricultural losses due to salinity and waterlogging are expected to reach about Rs. 860 million (US\$ 28.5 million).

A new biological approach 'plant-microbe interaction' to conquer salinity troubles has recently gained a great interest from many workers throughout the world $(1 ; 6)$. Bacteria beneficially help the plant in a direct or indirect way, causing in the stimulation of its growth $(16 ; 17 ; 24)$. Natural population of saline environments with better adaptive strategies, halophilic/halotolerant bacteria are environmentally friendly option to apply as biocontrol mediators to ameliorate salt stress (4). Nitrogen fixing bacteria have been shown to modify the properties of saline soil by adding nitrogen in to the soil (8). Earlier Yasmin and Hasnain (23) isolated plasmid harboring halophilic/halotolerant bacteria and their plant microbe interaction experiments showed the ability to promote growth of different plants in laboratory conditions (14). Such findings showed that genes responsible for the salt tolerance may serve as a foundation in the success of plant-microbe interaction in saline soil. Hence the present study was conducted to assess 
whether the salt tolerant bacterial plasmids (wild as well as in transformed strains) have some role in plant growth stimulation under salt stress conditions.

\section{MATERIALS AND METHODS}

\section{Bacterial strains}

Eleven salt tolerant bacterial strains (SP-3, SP-4, SP-7, PT-5, PT-6, HT-7, HAa2, PEh1, ST-1, ST-2 and ST-9) isolated from various sources (Table 1) were routinely grown on L-agar medium (7) supplemented with $2 \mathrm{M} \mathrm{NaCl}$.

\section{Transformation of strains}

For transformation, Thomas (21) method was followed.
Plasmid DNAs from salt tolerant bacteria (SP-3, SP-4, SP-7, PT-5, PT-6, HT-7, HAa2, PEh1, ST-1, ST-2, ST-9) were isolated and transformed to Escherichia coli K12 strain C600 which was used as recipient (able to grow in the presence 0.1 $\mathrm{M} \mathrm{NaCl}$ on L-agar, but can not grow at $0.5 \mathrm{M} \mathrm{NaCl}$ ). All the eleven transformants of Escherichia coli K12 strain C600 (E. coli-SP-3-T, E. coli-SP-4-T, E. coli-SP-7-T, E. coli-PT-5-T, E. coli-PT-6-T, E. coli-HT-7-T, E. coli-HAa2-T, E. coli-PEh1-T, E. coli-ST-1-T, E. coli-ST-2-T, E. coli-ST-9-T) were able to tolerate up to $1.5-2.0 \mathrm{M} \mathrm{NaCl}$ in the growth medium. Plasmid was isolated following the method of Smith and Thomas (19). All the parental strains contain a single plasmid of size varying from 78 to $125 \mathrm{kbp}$.

Table 1. Salt tolerant bacterial strains and their respective transformants used for plant growth experiments under $100 \mathrm{mM} \mathrm{NaCl}$ stress in laboratory conditions.

\begin{tabular}{lll}
\hline PARENT STRAINS & SOURCE & TRANSFORMED STRAINS \\
\hline SP-3 & Saline soil sample & E. coli-SP-3-T \\
SP-4 & Saline soil sample & E. coli-SP-4-T \\
SP-7 & Saline soil sample & E. coli-SP-7-T \\
PT-5 & Launea nudicaulis (Phylloplane) & E. coli-PT-5-T \\
PT-6 & Launea nudicaulis (Phylloplane) & E. coli-PT-6-T \\
HT-7 & Astragalus sp. (Histoplane) & E. coli-HT-7-T \\
Bacillus subtilis HAa2 & Achyranthus aspera (Histoplane) & E. coli-HAa2-T \\
PEh1 & Euphorbia heliscopia (Phylloplane) & E. coli-PEh1-T \\
Halomonas aquamarina ST-9 & Astragalus sp. (Rhizosphere soil) & E. coli-ST-9-T \\
Staphylococcus xylosus ST-1 & Mazus sp. (Rhizosphere) & E. coli-ST-1-T \\
Halomonas pacifica ST-4 & Mazus sp. (Rhizosphere) & E. coli-ST-4-T
\end{tabular}

\section{Plant growth experiments}

Seeds sterilization and inoculation: Certified seeds of Triticum aestivum var Inqlab-91 were obtained from National Agriculture Research Center-NARC, Islamabad, Pakistan. Seeds were surface sterilized and inoculated with bacterial suspension (1).

\section{Experimental set-up}

Petriplates were lined with double layer of wattman filter paper and supplied with $10 \mathrm{ml}$ of autoclaved distilled water.
Inoculated seeds were uniformly spread in the petriplate (20 seeds in each petriplate) with the help of sterilized forcep. All the plates were kept in dark at $24 \pm 2{ }^{\circ} \mathrm{C}$ for three days. Germination process was noticed daily. After germination, 10 $\mathrm{ml}$ of Hewitts (10) nutrient solutions was added to supplement the nutrient requirements of the seedlings and plates were shifted to light (10 Klux for 16 hours at $24 \pm 2^{\circ} \mathrm{C}$ ). Seedlings were harvested after 10 days and different growth parameters (germination, seedling length, fresh weight, moisture content) were recorded. 


\section{Biochemical parameters}

For estimation of $\mathrm{Na}^{+} / \mathrm{K}^{+}$contents of seedlings, digestion of plant material was done according to the method of Humphries (12). Seed coats of the oven dried seedlings were crushed and $10 \mathrm{ml}$ of conc. $\mathrm{HNO}_{3}$ and $2 \mathrm{ml}$ of $\mathrm{HClO}_{4}$ was added and digested by heating on the sand bath until clear white fumes appeared. Digested material was diluted to $10 \mathrm{ml}$ and the $\mathrm{Na}^{+} / \mathrm{K}^{+}$content was analyzed using flame photometer.

Following Mahadevan (13) auxin was extracted form shoots of plants. Frozen plant material was crushed in the presence of $2 \mathrm{ml}$ of ethyl ether and centrifuge to get supernatant. Supernatant was mixed with $1 \mathrm{ml}$ of $5 \%$ sodium bicarbonate, shaken and sodium bicarbonate layer was acidified to $\mathrm{pH} 3$ with $\mathrm{HCl}(6 \mathrm{~N})$. Then add $1 \mathrm{ml}$ of ethyl ether and in the organic layer $2 \mathrm{ml}$ of Salkowski's reagent was added in each test tube. This material was kept in dark at room temperature for $30 \mathrm{~min}$ for color development. Auxin content in the extract was determined with the help spectrophotometer at $535 \mathrm{~nm}$. Soluble proteins were extracted following method of Bhatti et al. (5). Frozen plant material was crushed in phosphate buffer $(0.1 \mathrm{M} \mathrm{pH} \mathrm{7.0)}$ at a ration of $1: 4(\mathrm{w} / \mathrm{v})$. Sample was centrifuged $\left(14,000 \mathrm{rpm}\right.$ for 10 minutes at $\left.4^{\circ} \mathrm{C}\right)$ and supernatant $(0.4 \mathrm{ml})$ was mixed with $2 \mathrm{ml}$ of Folin's mixture and let it at room temperature for $15 \mathrm{~min}$. After this 0.2 $\mathrm{ml}$ of Folin and Ciocalteu's phenol reagent was mixed and placed for $45 \mathrm{~min}$ at room temperature for the color development. Optical density was taken at $750 \mathrm{~nm}$ and soluble protein was calculated using standard curve.

\section{S rRNA Sequencing}

To confirm taxonomic identity, strains ST-1, ST-4, ST-9 and HAa2 which showed promising results, 16S rRNA gene sequencing was undertaken. A part of the 16S rRNA gene (500 bp) was amplified using the primer (5'-GAGTTTGATCCTGG CTCAG-3') and (5'-GTTACCTTGTTACGACTT-3'). PCR was performed with a mixtures $(50 \mu \mathrm{l})$ consisted of $2.5 \mathrm{mM} \mathrm{MgCl}_{2}$, $10 \mathrm{mM}$ Tris- $\mathrm{HCl}(\mathrm{pH} \mathrm{9.0),} 50 \mathrm{mM} \mathrm{KCl,} 0.1 \%$ Triton $\mathrm{X}-100$, $0.2 \mathrm{mM}$ each dNTP, $1.25 \mathrm{U}$ of Taq polymerase (Perkin-Elmer
Applied Biosystems), and $0.5 \mu \mathrm{M}$ primer. A 5- $\mu$ l volume of the bacterial genomic DNA in the TE (10 mM Tris-HCl, $\mathrm{pH} 7.4 ; 1$ mM EDTA) buffer was used following initial denaturation at 2 min at $95{ }^{\circ} \mathrm{C}$ followed by 45 repeats of $15 \mathrm{~s}$ at $95^{\circ} \mathrm{C}$, and $1 \mathrm{~min}$ at $64{ }^{\circ} \mathrm{C}$ and final extension for $10 \mathrm{~min}$ and $64{ }^{\circ} \mathrm{C}$. Forward and reverse sequencing reactions were carried out for amplified product. For the sequencing reaction $3 \mu \mathrm{l}$ of product, $4 \mu \mathrm{l}$ of distilled water and $13 \mu \mathrm{l}$ of MicroSeq sequencing mix was taken and all sequence analysis was carried on an ABI PRISM automated DNA sequencer and the data obtained was compared to the MicroSeq ${ }^{\circledR}$ databases (ACCUGENIX ${ }^{\mathrm{TM}}$ Newark DE 19702).

\section{Statistical analysis}

Standard errors of the means and LSD were calculated following Steel and Torrie (20).

\section{RESULTS}

\section{Strains identification}

Identification of isolates ST-1, ST-4, ST-9 and HAa2 based on their gene sequence (500 bp 16S rRNA), placed them as Staphylococcus xylosus ST-1, Halomonas pacifica ST-4, Halomonas aquamarina ST-9 and Bacillus subtilis HAa2, respectively. All the eleven transformants of Escherichia coli K12 strain $\mathrm{C} 600$ could tolerate up to $2 \mathrm{M} \mathrm{NaCl}$ stress which showed that the salt tolerant genes were present on the plasmid. Seed germination

Salt stress caused reduction $(19 \%)$ in seed germination (Table 2) over non-inoculated control plants. In general, bacterial inoculations stimulated germination with and without salt stressed conditions. Without salt stress, parental strain $H$. aquamarina ST-9 caused 10\% increases in seed germination over respective non-inoculated control. At $100 \mathrm{mM} \mathrm{NaCl}$, parental strain S. xylosus ST-1 and transformed strain HAa2-T caused $16 \%$ and $10 \%$ increment, respectively, in seed germination over non-inoculated control and $16 \%$ and $17 \%$, respectively, as compared to E. coli C600. 
Table 2. Effect of salt tolerant bacteria (parental strains and their respective transformants) on \%age germination of $T$. aestivum under control (without $\mathrm{NaCl}$ stress) and $\mathrm{NaCl}$ stress $(100 \mathrm{mM})$. (means of four replicates).

\begin{tabular}{|c|c|c|}
\hline STRAINS & CONTROL & $100 \mathrm{mM}$ \\
\hline Control & $90.0 \pm 0.00$ & $72.5 \pm 1.76$ \\
\hline E. coli $\mathrm{C} 600$ & $92.5 \pm 1.76$ & $77.5 \pm 1.76$ \\
\hline SP-3 & $90.0 \pm 0.00$ & $77.5 \pm 1.76$ \\
\hline E. coli-SP-3-T & $85.0 \pm 3.53$ & $82.5 \pm 1.76$ \\
\hline SP-4 & $92.5 \pm 5.30$ & $80.0 \pm 7.07$ \\
\hline E. coli- SP-4-T & $70.0 \pm 3.53$ & $65.0 \pm 3.53$ \\
\hline SP-7 & $87.5 \pm 1.76$ & $77.5 \pm 1.76$ \\
\hline E. coli- SP-7-T & $87.5 \pm 1.76$ & $77.5 \pm 1.76$ \\
\hline PT-5 & $95.0 \pm 0.00$ & $77.5 \pm 5.30$ \\
\hline E. coli- $\mathrm{PT}-5-\mathrm{T}$ & $77.5 \pm 1.76$ & $67.5 \pm 1.76$ \\
\hline PT-6 & $92.5 \pm 5.30$ & $82.5 \pm 5.30$ \\
\hline E. coli- $\mathrm{PT}-6-\mathrm{T}$ & $82.5 \pm 1.76$ & $62.5 \pm 1.76$ \\
\hline HT-7 & $90.0 \pm 3.53$ & $82.5 \pm 5.30$ \\
\hline E. coli- HT-7-T & $80.0 \pm 7.07$ & $65.0 \pm 0.00$ \\
\hline HAa2 & $90.0 \pm 1.76$ & $75.0 \pm 3.53$ \\
\hline E. coli- HAa2-T & $92.5 \pm 1.76$ & $85.0 \pm 0.00$ \\
\hline PEh1 & $92.5 \pm 0.00$ & $62.5 \pm 1.76$ \\
\hline E. coli- PEh1-T & $92.5 \pm 1.76$ & $77.5 \pm 1.76$ \\
\hline ST-9 & $100.0 \pm 0.00$ & $77.5 \pm 5.30$ \\
\hline E. coli- ST-9-T & $86.0 \pm 1.56$ & $68.5 \pm 2.10$ \\
\hline ST-1 & $93.0 \pm 2.15$ & $84.0 \pm 3.20$ \\
\hline E. coli- $\mathrm{ST}-1-\mathrm{T}$ & $89.5 \pm 1.67$ & $65.0 \pm 2.00$ \\
\hline ST-4 & $95.0 \pm 2.00$ & $77.5 \pm 1.95$ \\
\hline E. coli- ST-4-T & $86.5 \pm 1.50$ & $67.0 \pm 3.50$ \\
\hline \multicolumn{3}{|l|}{ LSD at $p=0.05$} \\
\hline For Strain & \multicolumn{2}{|r|}{2.70} \\
\hline For Treatment & \multicolumn{2}{|c|}{19.5} \\
\hline
\end{tabular}

\section{Length parameters}

Salinity also caused reduction in seedling growth (46\%) over control (Table 3). Some parental and transformed strains caused reduction in shoot growth without $\mathrm{NaCl}$ stress compared to plants inoculated with E. coli C600 as well as control. While seedling inoculated with B. subtilis HAa2 caused $6 \%$ enhancement in this parameter, over non-inoculated control at $100 \mathrm{mM}$, strain S. xylosus ST-1 caused $25 \%$ increments in seedling length over respective non-inoculated control.

Most of the transformants at $100 \mathrm{mM}$ caused reduction in this parameter comparison to non-inoculated control. Transformed strain E. coli-SP-4-T resulted $9.8 \%$ increment in growth over control E. coli C600 (table 3).

\section{Weight parameters}

Salt stress inhibited fresh weight $(83 \%)$ of $T$. aestivum seedlings as compared to salt free control (Table 3). Almost all parental strains (except SP-3) positively affected (0.2 to $42 \%$ ) fresh weight, while majority of the transformants induced reduction in fresh weight per seedling under salt free conditions over non-inoculated control. At $100 \mathrm{mM} \mathrm{NaCl}$ bacterial inoculation SP-7 exhibited significant increase (64\%) in fresh weight compared to control. Transformed strain $E$. coli-PEh1-T resulted about 35\% increments over respective control under $100 \mathrm{mM} \mathrm{NaCl}$ stress. 
Table 3. Effect of salt tolerant bacteria (parental strains and their respective transformants) on seedling length and fresh weight of T. aestivum seedlings grown under control (without $\mathrm{NaCl}$ stress) and $\mathrm{NaCl}$ stress $(100 \mathrm{mM})$. (means of four replicates).

\begin{tabular}{|c|c|c|c|c|}
\hline \multirow[t]{2}{*}{ STRAINS } & \multicolumn{2}{|c|}{ SEEDLING LENGTH (cm) } & \multicolumn{2}{|c|}{ FRESH WEIGHT PER SEEDLING (mg) } \\
\hline & $0 \mathrm{mM}$ & $100 \mathrm{mM}$ & $\mathbf{0 ~ m M}$ & $100 \mathrm{mM}$ \\
\hline Control & $34.38 \pm 1.14$ & $18.73 \pm 0.85$ & $450.83 \pm 24.03$ & $274.00 \pm 11.42$ \\
\hline E. coli $\mathrm{C} 600$ & $33.71 \pm 0.38$ & $16.96 \pm 0.53$ & $462.18 \pm 12.01$ & $289.38 \pm 9.61$ \\
\hline SP-3 & $34.06 \pm 1.43$ & $20.24 \pm 1.67$ & $396.29 \pm 9.87$ & $289.09 \pm 11.07$ \\
\hline E. coli-SP-3-T & $34.28 \pm 0.72$ & $17.05 \pm 0.99$ & $400.83 \pm 10.98$ & $273.16 \pm 16.04$ \\
\hline SP-4 & $32.29 \pm 1.25$ & $22.43 \pm 1.13$ & $470.00 \pm 23.13$ & $357.77 \pm 11.75$ \\
\hline E. coli- $\mathrm{SP}-4-\mathrm{T}$ & $32.21 \pm 1.11$ & $20.58 \pm 1.50$ & $406.15 \pm 8.38$ & $330.91 \pm 14.26$ \\
\hline SP-7 & $35.15 \pm 1.72$ & $23.15 \pm 1.04$ & $470.91 \pm 7.96$ & $450.00 \pm 19.86$ \\
\hline E. coli- $\mathrm{SP}-7-\mathrm{T}$ & $32.52 \pm 1.98$ & $17.05 \pm 0.96$ & $417.86 \pm 9.39$ & $362.50 \pm 14.56$ \\
\hline PT-5 & $29.18 \pm 0.77$ & $20.98 \pm 0.78$ & $486.36 \pm 9.13$ & $300.72 \pm 14.61$ \\
\hline E. coli- $\mathrm{PT}-5-\mathrm{T}$ & $33.47 \pm 1.43$ & $16.45 \pm 0.71$ & $375.00 \pm 7.87$ & $292.31 \pm 12.39$ \\
\hline PT-6 & $36.29 \pm 0.97$ & $20.09 \pm 1.22$ & $489.09 \pm 11.76$ & $366.67 \pm 21.87$ \\
\hline E. coli- PT-6-T & $34.04 \pm 1.76$ & $15.76 \pm 0.90$ & $440.77 \pm 12.84$ & $237.14 \pm 17.59$ \\
\hline HT-7 & $35.89 \pm 2.13$ & $22.41 \pm 1.43$ & $550.00 \pm 9.01$ & $345.55 \pm 13.36$ \\
\hline E. coli- HT-7-T & $29.66 \pm 1.55$ & $18.52 \pm 1.56$ & $450.83 \pm 7.66$ & $345.34 \pm 11.48$ \\
\hline HAa2 & $36.61 \pm 1.98$ & $22.66 \pm 1.45$ & $566.36 \pm 12.55$ & $305.45 \pm 8.49$ \\
\hline E. coli- HAa2-T & $35.27 \pm 2.33$ & $18.50 \pm 1.74$ & $463.85 \pm 10.78$ & $273.33 \pm 6.76$ \\
\hline PEh1 & $33.44 \pm 1.99$ & $20.34 \pm 0.98$ & $641.00 \pm 15.67$ & $402.22 \pm 12.93$ \\
\hline E. coli- PEh1-T & $33.22 \pm 2.12$ & $20.19 \pm 1.32$ & $435.38 \pm 21.44$ & $368.75 \pm 921$ \\
\hline ST-9 & $35.26 \pm 1.65$ & $22.34 \pm 1.38$ & $483.85 \pm 13.37$ & $292.22 \pm 19.34$ \\
\hline E. coli-ST-9-T & $32.50 \pm 2.1$ & $16.50 \pm 0.52$ & $395.24 \pm 14.21$ & $245.23 \pm 10.5$ \\
\hline ST-1 & $36.15 \pm 1.5$ & $23.42 \pm 1.2$ & $512.20 \pm 15.3$ & $395.54 \pm 13.5$ \\
\hline E. coli- ST-1-T & $33.50 \pm 1.0$ & $18.25 \pm 0.39$ & $432.32 \pm 11.5$ & $256.24 \pm 16.0$ \\
\hline ST-4 & $35.54 \pm 0.68$ & $22.60 \pm 0.84$ & $498.52 \pm 15.4$ & $423.16 \pm 12.3$ \\
\hline E. coli- ST-4-T & $32.85 \pm 1.40$ & $18.00 \pm 1.0$ & $444.21 \pm 13.2$ & $281.26 \pm 10.6$ \\
\hline \multicolumn{5}{|l|}{ LSD at $p=0.05$} \\
\hline For Strain & \multicolumn{2}{|c|}{1.06} & \multicolumn{2}{|c|}{25.8} \\
\hline For Treatment & \multicolumn{2}{|c|}{7.66} & \multicolumn{2}{|c|}{186} \\
\hline
\end{tabular}

\section{Moisture content}

Moisture content of seedlings reduced under salt stress (Fig. 1). At $0 \mathrm{mM}$, majority of the bacterial inoculations caused enhancements and some caused reductions in moisture content of seedlings. However at $100 \mathrm{mM}$ all the parental and HAa2 inoculations induced significant increase in moisture content.

\section{Biochemical aspects}

Auxin content: Salt stress resulted an in increase (132\%) in auxin level of $T$. aestivum seedlings over when compared with control plants (Table 4). Parental strain SP-7 caused 53\% increment in auxin activity in seedlings over respective non- inoculated control. Majority of the transformant strains caused a reduction in auxin synthesis by seedlings grown without $\mathrm{NaCl}$, in comparison to seedlings inoculated with E. coli C600 as well as control plants. At $100 \mathrm{mM} \mathrm{NaCl}$, generally transformants resulted a decrease in auxin content of seedlings over non-inoculated seedlings and in majority of the cases auxin level still high over those of E. coli C600 treated seedlings. Under salt stress, parental (B. subtilis HAa2) and transformed (E. coli-SP-7-T) strains promoted auxin level 33\% and $30 \%$, respectively, non-inoculated respective control (Table 4). 


\section{Soluble protein content}

Soluble protein content significantly enhanced (49\%) under salt stress as compared to salt free control (Table 4). Without stress strain S. xylosus ST-1 caused an increment of treatment.
$20 \%$ over respective non-inoculated control. At $100 \mathrm{mM} \mathrm{NaCl}$, maximum enhancement (32\%) in protein content was observed in case of parental strain PT-5 over respective control
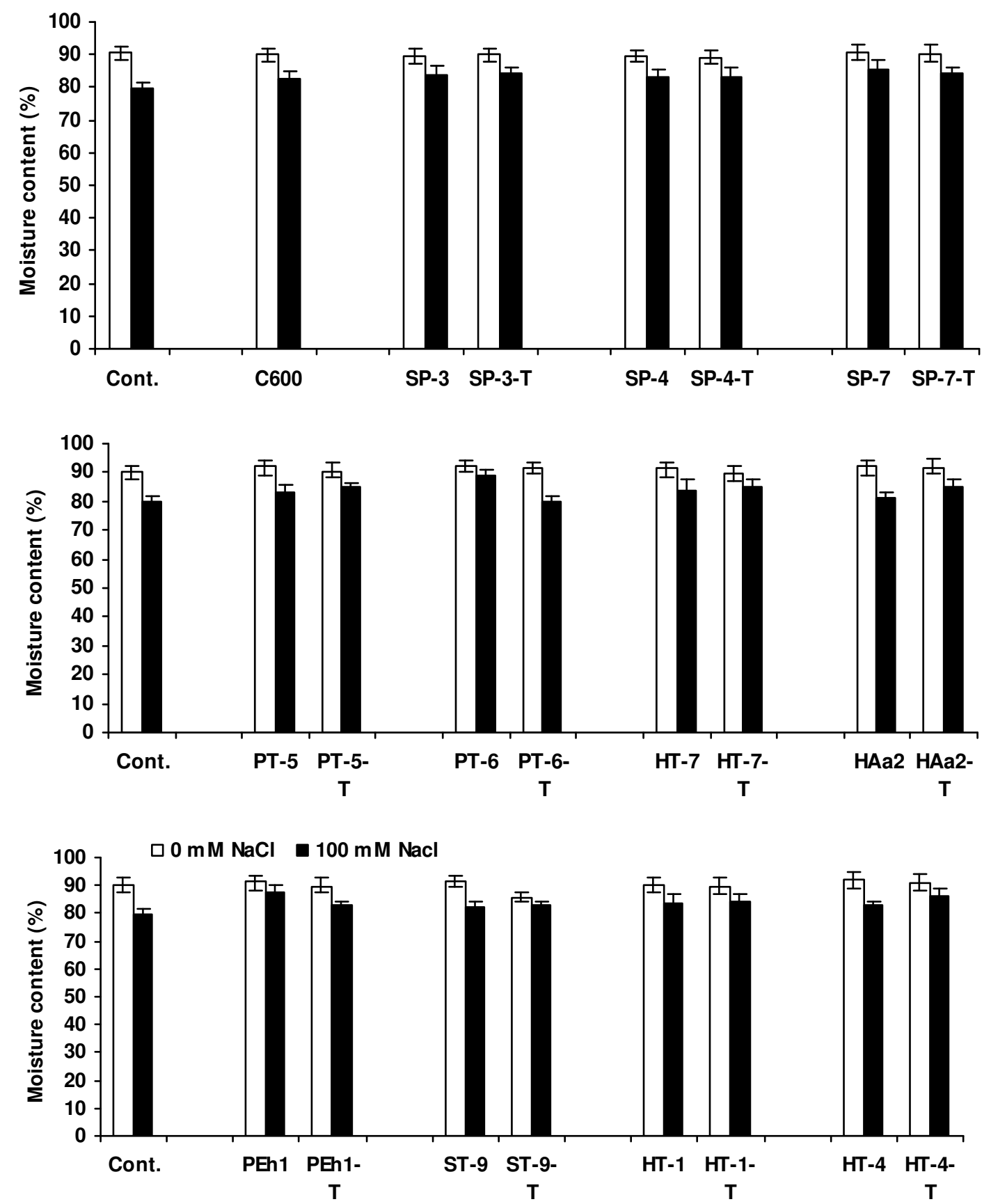

Figure 1. Effect of inoculation of salt tolerant bacteria (parent strains and their transformants) on moisture content (\%) of $T$. aestivum seedlings under $\mathrm{NaCl}$ stress 
Table 4. Effect of salt tolerant bacteria (parental strains and their respective transformants) on auxin and soluble protein content of T. aestivum seedlings grown under control (without $\mathrm{NaCl}$ stress) and $\mathrm{NaCl}$ stress $(100 \mathrm{mM})$. (means of four replicates).

\begin{tabular}{|c|c|c|c|c|}
\hline \multirow[t]{2}{*}{ STRAINS } & \multicolumn{2}{|c|}{ AUXIN CONTENT ( $\mu$ g / g. f. wt.) } & \multicolumn{2}{|c|}{ SOLUBLE PROTEIN CONTENT ( $\mu$ g / g. f. wt.) } \\
\hline & $0 \mathrm{mM}$ & $100 \mathrm{mM}$ & $0 \mathrm{mM}$ & $100 \mathrm{mM}$ \\
\hline Control & $0.73 \pm 0.01$ & $1.69 \pm 0.11$ & $657.98 \pm 11.3$ & $977.28 \pm 13.5$ \\
\hline E. coli $\mathrm{C} 600$ & $0.68 \pm 0.04$ & $1.61 \pm 0.11$ & $664.19 \pm 12.4$ & $998.87 \pm 12.7$ \\
\hline SP-3 & $0.69 \pm 0.007$ & $1.43 \pm 0.09$ & $699.16 \pm 28.5$ & $1145.96 \pm 20.7$ \\
\hline E. coli-SP-3-T & $0.54 \pm 0.001$ & $1.55 \pm 0.004$ & $634.87 \pm 17.8$ & $998.54 \pm 26.2$ \\
\hline SP-4 & $1.02 \pm 0.02$ & $1.74 \pm 0.10$ & $792.46 \pm 15.0$ & $1051.36 \pm 54.1$ \\
\hline E. coli- SP-4-T & $0.86 \pm 0.09$ & $1.39 \pm 0.05$ & $715.64 \pm 31.8$ & $957.65 \pm 34.7$ \\
\hline SP-7 & $1.12 \pm 0.001$ & $1.90 \pm 0.14$ & $725.43 \pm 27.5$ & $1275.56 \pm 23.5$ \\
\hline E. coli- SP-7-T & $0.75 \pm 0.009$ & $2.19 \pm 0.15$ & $706.61 \pm 22.1$ & $1089.73 \pm 51.4$ \\
\hline PT-5 & $0.71 \pm 0.002$ & $1.99 \pm 0.15$ & $705.52 \pm 34.2$ & $1286.37 \pm 24.9$ \\
\hline E. coli- PT-5-T & $0.48 \pm 0.05$ & $1.66 \pm 0.01$ & $729.71 \pm 22.3$ & $1091.11 \pm 52.1$ \\
\hline PT-6 & $0.94 \pm 0.07$ & $1.77 \pm 0.11$ & $677.50 \pm 8.6$ & $1137.51 \pm 37.4$ \\
\hline E. coli- $\mathrm{PT}-6-\mathrm{T}$ & $0.61 \pm 0.03$ & $1.37 \pm 0.02$ & $657.80 \pm 31.2$ & $992.76 \pm 32.4$ \\
\hline HT-7 & $1.01 \pm 0.05$ & $2.11 \pm 0.15$ & $747.61 \pm 27.7$ & $1050.81 \pm 22.7$ \\
\hline E. coli- HT-7-T & $0.91 \pm 0.01$ & $1.87 \pm 0.10$ & $715.69 \pm 20.5$ & $941.24 \pm 23.5$ \\
\hline HAa2 & $0.76 \pm 0.001$ & $2.25 \pm 0.11$ & $613.42 \pm 35.2$ & $958.62 \pm 31.9$ \\
\hline E. coli- HAa2-T & $0.64 \pm 0.05$ & $1.59 \pm 0.03$ & $675.18 \pm 32.5$ & $867.14 \pm 28.1$ \\
\hline PEh1 & $0.88 \pm 0.06$ & $1.91 \pm 0.09$ & $734.15 \pm 29.2$ & $745.99 \pm 29.8$ \\
\hline E. coli- PEh1-T & $0.71 \pm 0.01$ & $1.79 \pm 0.001$ & $695.23 \pm 26.3$ & $718.55 \pm 21.4$ \\
\hline ST-9 & $1.00 \pm 0.007$ & $1.87 \pm 0.09$ & $735.91 \pm 18.9$ & $1208.74 \pm 32.5$ \\
\hline E. coli- ST-9-T & $0.65 \pm 0.004$ & $1.54 \pm 0.01$ & $623.12 \pm 16.5$ & $852.25 \pm 24.5$ \\
\hline ST-1 & $1.08 \pm 0.002$ & $2.11 \pm 0.02$ & $789.34 \pm 13.5$ & $1195.12 \pm 23.5$ \\
\hline E. coli- $\mathrm{ST}-1-\mathrm{T}$ & $0.68 \pm 0.001$ & $1.64 \pm 0.009$ & $645.38 \pm 15.8$ & $898.20 \pm 24.64$ \\
\hline ST-4 & $0.98 \pm 0.007$ & $1.98 \pm 0.03$ & $695.89 \pm 20.1$ & $1084.01 \pm 36.41$ \\
\hline E. coli- ST-4-T & $0.73 \pm 0.006$ & $1.72 \pm 0.04$ & $682.54 \pm 16.5$ & $925.65 \pm 32.45$ \\
\hline \multicolumn{5}{|l|}{ LSD at $p=0.05$} \\
\hline For Strain & \multicolumn{2}{|c|}{0.08} & \multicolumn{2}{|c|}{58.1} \\
\hline For Treatment & \multicolumn{2}{|c|}{0.60} & \multicolumn{2}{|c|}{419} \\
\hline
\end{tabular}

\section{$\mathrm{Na}^{+} / \mathrm{K}^{+}$ratio}

Seedlings subjected to salt stress showed significant increases in $\mathrm{Na}^{+} / \mathrm{K}^{+}$ratios (Fig. 2). With the application of bacterial inoculations generally enhancement in $\mathrm{Na}^{+} / \mathrm{K}^{+}$ratios was recorded in salt free conditions, over non-inoculated control, except SP-7-T, HT-7, HM t2, HT-1 and HT- 4 strains that did not enhance the $\mathrm{Na}^{+} / \mathrm{K}^{+}$ratios. At $100 \mathrm{mM} \mathrm{NaCl}$ stress, bacterial inoculation tend to either increase (SP-3, SP-4, SP-4T, SP-7, SP-7-T) or decrease (SP-3-T, PT-5, PT-5-T, PT-6, PT6-T, HT-7, HT-7-T, HAa-2, HAa-2-T, HMt-2, HMt2-T, ST-9, ST-9-T, HT-1, HT-1-T, HT-4, HT-4-T) in $\mathrm{Na}^{+} / \mathrm{K}^{+}$ratio of seedlings and generally the decreases (2\% to $57 \%$ ) were observed with different transformant and parent inoculations. 

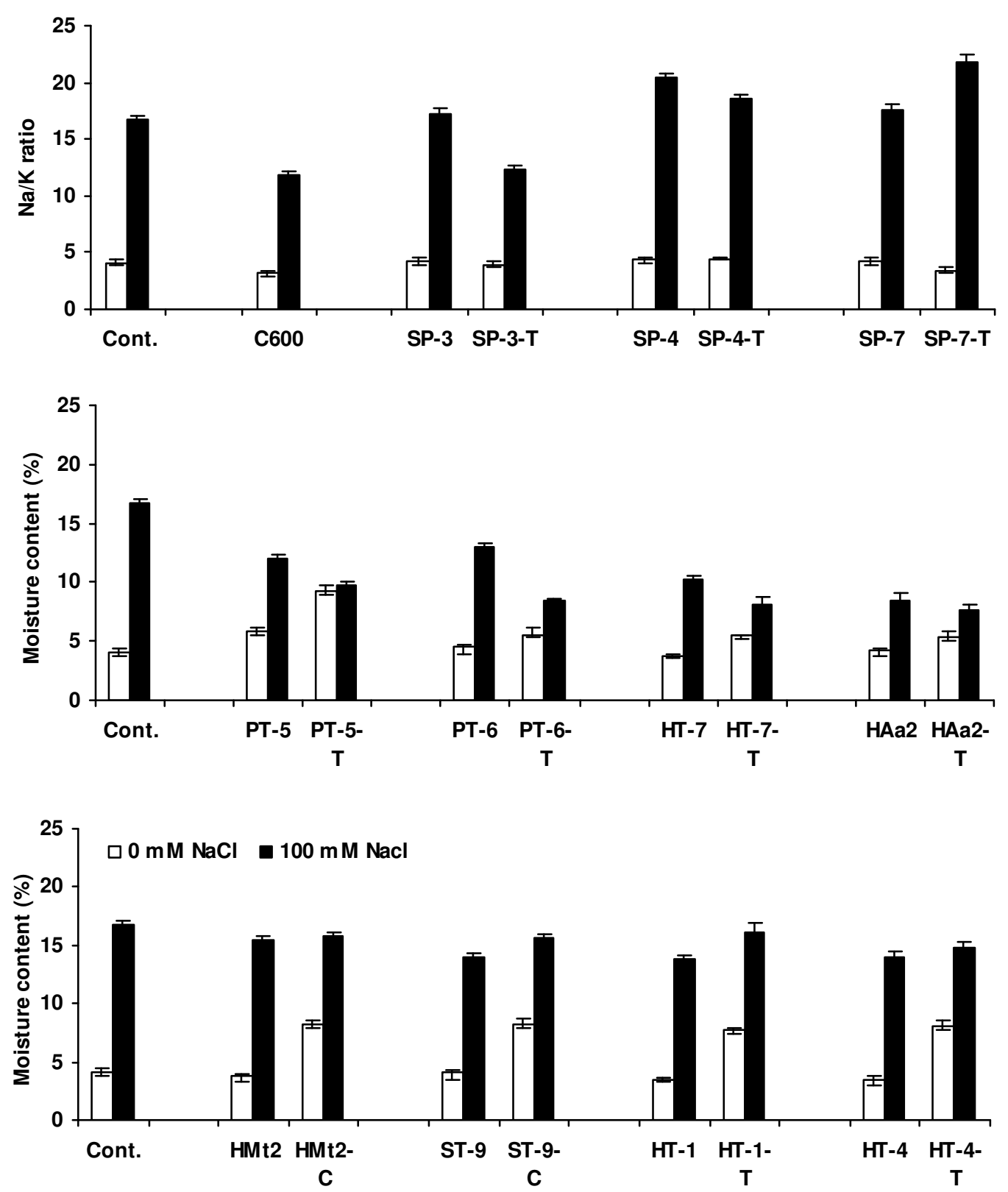

Figure 2. Effect of inoculation of salt tolerant bacteria (parent strains and their transformants) on $\mathrm{Na} / \mathrm{K}$ ratio of $T$. aestivum seedlings under $\mathrm{NaCl}$ stress.

\section{DISCUSSION}

Generally bacterial inoculations (E. coli C600, salt tolerant parental and transformants strains) enhanced seed germination both with and without $\mathrm{NaCl}$ stress in comparison to control treatments. Majority of bacterial inoculations promoted shoot growth of $T$. aestivum, whereas some of the inoculations (transformants) inhibited this parameter. According to some reports transformant strains were found to produce better results compared to parental inoculations in plant microbe interaction experiments. Holguin and Glick (11) found that in pouch and pot experiments, inoculation of tomato seedlings with transformants of Azospirillum brasilense Cd/pRKLACC (having gene responsible for high ACC deaminase activity) had 
significantly longer roots and increased root dry weight compared to non-treated plants or plants inoculated with nontransformed strain at an inoculum density of $10^{7} \mathrm{cfu} / \mathrm{ml}$. Roest et al. (18) reported the introduction of Sym plasmid pRL1JI from Rhizobium leguminosarum bv. viciae into a cured strain R. leguminosarum bv. trifolii RCR5 and results showed that transformed strain RBL5523 effectively caused nodulation in Vicia sativa plant. According to van Dillewijn et al. (22) introduction of putA gene into plasmid of Sinorhizobium meliloti, increased the competitiveness of the strain over parent strain as well as control in field especially in drought stress conditions. Our results with majority of the transformants disagree with these findings, so it suggests plasmids are not involved or the genes responsible for plant growth promotion are not present on plasmids. This also indicates that introduction of a new plasmid reduces fitness of the host cell or loses its some of the characteristics. Like seedling growth, parental inoculations yielded significant increase in fresh weight compared to plants treated with $E$. coli, and transformant strains both with and without stress.

Accumulation of ions in the vacuole is clearly one of the most important strategies employed by plant cells against salt stress (15). Seedlings subjected to salt stress showed significant increases in $\mathrm{Na}^{+} / \mathrm{K}^{+}$ratios. With the application of bacterial inoculations (parental and transformants) generally enhancement in $\mathrm{Na}^{+} / \mathrm{K}^{+}$ratios, compared to seedlings inoculated with $E$. coli and non-inoculated control seedlings, under salt free conditions, were recorded. At $100 \mathrm{mM} \mathrm{NaCl}$ treatment, transformants and their respective parental strains cause either increase or decrease in $\mathrm{Na}^{+} / \mathrm{K}^{+}$ratios under salt stress. According to Hasegawa et al. (9) if $\mathrm{Na}^{+}$ions are sequestered in the vacuole of a cell, $\mathrm{K}^{+}$and organic solutes should accumulate in the cytoplasm to balance the osmotic pressure of the ions in the vacuole. Hence the reduction in $\mathrm{Na}^{+} / \mathrm{K}^{+}$ratios in seedlings are due to reduction in $\mathrm{Na}^{+}$and increase in $\mathrm{K}^{+}$values of seedlings under salt stress. The decreased $\mathrm{Na}^{+} / \mathrm{K}^{+}$ratios in inoculated seedlings showed the ability of bacteria to accumulate $\mathrm{K}^{+}$in their initial response to external osmolarity to counteract the immediate outflow of water from the cell.

A general trend of increase in auxin content in seedlings inoculated with parent strains was observed. Most of the transformants lowered auxin level of seedlings. It has been reported that ipdc gene is involved in IAA biosynthesis in Pseudomonas putida. The comparison of non-inoculated seedlings, seedlings inoculated with mutant strain ( $P$. putida strain lacking ipdc gene) and with wild strain (having ipdc gene), showed that wild type strain produced three times higher IAA and significant stimulation in root compared to mutant strain (2). In the present study rise in higher auxin content, and more improved growth of seedlings with parental strains compared to transformants under salt stress may be considered as one of the mechanism of salt tolerant bacteria involved in plant growth promotion. Hence the increase in enzyme activities may lead to increased tolerance to abiotic stresses.

In sum, parental strain's inoculations caused pronounced stimulation in seedling growth under salt stress. Some of the transformant's inoculations negatively affected the growth of T. aestivum seedlings under salt stress. It may be possible that plasmids are not involved or the genes responsible for plant growth promotion are present on chromosome instead of plasmids. Less efficiency of transformants may be due to the reason that plasmids have lost its fitness or some of the characteristics. This can be confirmed by introducing the plasmids into another bacterium and can be further used for plant-microbe experiments. These preliminary results will pave the way to better understanding of the genetic factors involved in plant-bacteria relationship. It may also lead to confirm whether the genes involved in growth stimulation are present on plasmids or on chromosome. In advanced the gene responsible for salt tolerance in bacteria can be isolated and transformed to plants to produce salt resistant varieties and to promote saline agriculture.

\section{REFERENCES}

1. Adesemoye, A.O.; Obini, M.; Ugoji, E.O. (2008). Comparison of plant growth-promotion with Pseudomonas aeruginosa and Bacillus subtilis in three vegetables. Braz. J. Microbiol. 39, 423-426. 
2. Afrasayab, S.; Hasnain, S. (2000). Synergistic growth stimulatory effects of mixed culture bacterial inoculations on the early growth of Triticum aestivum under $\mathrm{NaCl}$ stress. Pak. J. Biol. Sci. 6, 1016-1023.

3. Ali, B.; Sabri, A. N; Ljung, K.; Hasnain, S. (2009). Auxin production by plant associated bacteria: impact on endogenous IAA content and growth of Triticum aestivum L. Lett. Appl. Microbiol. 48, 542-547.

4. Aslam, M.; Qureshi, R.H.; Nawaz, S.; Akhtar, J.; Nasim, M. (2000). Development of salt-affected wastelands for wood production in Pakistan. In: Nat Wshop "Woodfuel production and marketing in Pakistan”. Punjab Forestry Research Institute, Faisalabad, October 27-30, 1997. Bangkok, FAO Regional Wood Energy Development Programme in Asia, RWEDP Rep., 49: 51-64.

5. Bardavid, R.; Ionescu, D.; Oren, A.; Rainey, F.; Hollen, B.; Bagaley, D.; Small, A.; McKay, C. (2007). Selective enrichment, isolation and molecular detection of Salinibacter and related extremely halophilic bacteria from hypersaline environments. Hydrobiologia. 576, 3-13.

6. Bhatti, G. A.; Qureshi, N.; Qureshi, A.; Sultana, K. (1993). Studies on heat shock response of wheat seedlings using E. coli GroEL antibodies. Pakphyton. 5, 157-166.

7. Gamalero, E.; Berta, G.; Massa, N.; Glick, B.R.; Lingua, G. (2010). Interactions between Pseudomonas putida UW4 and Gigaspora rosea BEG9 and their consequences for the growth of cucumber under saltstress conditions. J. Appl. Microbiol. 108, 236-245.

8. Gerhardt, P.; Murray, R.G.E.; Wood, W.A.; Krieg, N.R. (1994). Methods for General and Molecular Bacteriology. American society for Microbiology, Washington, DC.

9. Govindarajan, M.; Balandreau, J.; Muthukumarasamy, R.; Revathi, G.; Lakshminarasimha, C. (2006). Improved yield of micropropagated sugarcane following inoculation by endophytic Burkholderia vietnamiensis. Plant Soil. 280, 239-252.

10. Hasegawa, P. M.; Bressan, R.A.; Zhu, J.K.; Bohnert, H.J. (2000). Plant cellular and molecular responses to high salinity. Plant Mol. Biol. 51, 463-499.

11. Hewitts, E.J. 1963. Mineral nutrition of plants in culture media. In: Steward, F.C. (eds). Plant Physiology. Academic Press, New York, p. $97-$ 133.

12. Holguin, G.; Glick, B.R. (2000). Inoculation of tomato plants with Azospirillum Brasilense Transformed with the ACC demaninase gene from enterobacter cloacae UW4. In: Proc. $5^{\text {th }}$ Int. PGPR workshop, Portal Del Lago Hotel and Resort Villa Carlos Paz Cordoba, Argentina.

13. Humphries, E.C. (1956). Mineral component and ash analysis. In: Paech, K., Tracey, M.Y. (eds). Modern Methods of Plant Analysis. Springer,
Berlin.

14. Mahadevan, A. (1984). Growth regulators, microorganisms and diseased plants. Oxford and IBH Publishing company, India, p. 31.

15. Mehr, S.; Afrasayab, S.; Hasnain, S. (2002). Effect of mono culture inoculations on the early growth of Triticum aestivum var Inqlab 91 under $\mathrm{NaCl}$ stress. Pak. J. Biol. Sci. 5, 643-647.

16. Mimura, T.; Kura-Hotta, M.; Tsujimura, T., Ohnishi, M.; Miura, M.; Okazaki, Y.; Mimura, M.; Maeshima, M.; Washitani-Nemoto, S. (2003). Rapid increase of vacuolar volume in response to salt stress. Planta. 216, 397-402.

17. Muthukumarasamy, R.; Kang, U.G.; Park, K.D.; Jeon, W.T.; Park, C.Y.; Cho, Y.S.; Kwon, S.W.; Song, J.; Roh, D.H.; Revathi, G. (2007). Enumeration, isolation and identification of diazotrophs from Korean wetland rice varieties grown with long-term application of $\mathrm{N}$ and compost and their short-term inoculation effect on rice plants. J. Appl. Microbiol. 102, 981-991.

18. Prrlak, L.; Kose, M. (2009). Effects of plant growth promoting rhizobacteria on yield and some fruit properties of strawberry. J. Plant Nutr. 32, 1173-1184.

19. Roest, H.P.; Mulders, I.H.M.; Spaink, H.P.; Wijffelman, C.A.; Lugtenberg, B.J.J. (1997). A Rhizobium leguminosarum Biovar trioflii locus not localized on the Sym plasmid hinders effective nodulation on plants of the pea cross-inoculation group. Mol. Plant Microb. Interat. 10, 938-941.

20. Smith, C.A.; Thomas, C.M. 1983. Deletion maping of Kil and Kor function in $\operatorname{trf} A$ and $\operatorname{trfB}$ regions of broad host range plasmid RK2. Mol. Gen. Genet., 190: 245-254.

21. Steel, R.G.D.; Torrie, J.H. (1981). Principles and Procedures of Statistics, a Biometrical Approach. McGraw Hill International Book Company.

22. Thomas, C.M. (1981). Completion analysis of replications and maintenance function of broad host range plasimds RK2 and RP1. Plasmid. 5, 277-291.

23. van Dillewijn, P.; Soto, M. J.; Villadas, P. J.; Toro, N. (2001). Construction and environmental release of a Sinorhozobium meliloti strain genetically modified to be more competitive for Alfalfa nodulation. Appl. Environ. Microbiol. 67, 3860-3865.

24. Yasmin, A.; Hasnain, S. (2001). Bacterial diversity in athalassic saline habitats. Pak. J. Microbiol. 1, 67-76.

25. Yobo, K.S.; Laing, M.D.; Hunter, C.H. (2009). Effects of single and dual applications of selected Trichoderma and Bacillus isolates on performance of dry bean seedlings grown in composted pine bark growth medium under shadehouse conditions. J. Plant Nutrit. 32, 1271-1289. 